\title{
Pengaruh Kompensasi Terhadap Kepuasan Kerja Dan Implikasinya Terhadap Kinerja Individu Perawat Pada Beberapa Rumah Sakit Swasta di Kota Medan
}

\author{
Aprinawati \\ Fauzia Agustini \\ Hilma Harmen \\ Program Studi Manajemen Fakultas Ekonomi \\ Universitas Negeri Medan \\ Email: aprinawati77@gmail.com, Fauziagustini24@gmail.com, \\ hilmaharmen@gmail.com
}

\begin{abstract}
ABSTRAK
Tujuan jangka panjang penelitian ini adalah untuk memberikan kontribusi pada manajemen rumah sakit swasta di kota medan agar dapat mendorong peningkatan kinerja Individu perawat sehingga menghasilkan pelayan prima terhadap pasien melalui kepuasan kerja sebagai aspek emosional yang dirasakan oleh perawat berdasarkan kompensasi yang mereka terima dari pihak rumah sakit. Adapun target khusus yang ingin dicapai adalah untuk mengetahui pengaruh kompensasi terhadap kepuasan dan untuk mengetahui pengaruh kepuasan kerja terhadap kinerja serta untuk mengetahui pengaruh kepuasan kerja terhadap kinerja individu perawat pada beberapa rumah sakit swata di kota medan. Adapun metode yang akan dipakai oleh penelitian ini adalah wawancara, penyebaran kuesioner, dan dokumentasi. Metode analisis yang digunakan adalah dengan Model persamaan Regresi.
\end{abstract}

Kata Kunci : Kompensasi, Kepuasan kerja dan kinerja individu

\begin{abstract}
The long-term objective of this study is to contribute to the management of private hospitals in the city of Medan in order to encourage the improvement of individual nurse performance so as to produce excellent service to patients through job satisfaction as an emotional aspect felt by nurses based on the compensation they receive from the hospital. The specific targets to be achieved are to determine the effect of compensation on satisfaction and to determine the effect of job satisfaction on performance and to determine the effect of job satisfaction on the performance of individual nurses at several private hospitals in the city of Medan. The methods that will be used by this research are interviews, questionnaires, and documentation. The method of analysis used is the regression equation model.
\end{abstract}

Keyword: Compensation, job satisfaction and individual performance 


\section{LIABILITIES (JURNALPENDIDIKAN AKUNTANSI) \\ e-ISSN 2620-5866 (Online) \\ http://jurnal.umsu.ac.id/index.php/LIAB \\ Vol. 4 No. 1 April 2021 Halaman 10 - 23 \\ Doi: 10.30596/liabilities.v4i1.6844}

\section{PENDAHULUAN}

Sumber daya manusia dalam suatu perusahaan merupakan aset yang sangat berharga. Kemajuan suatu perusahaan sangat dipengaruhi oleh baik tidaknya pengelolaan sumber daya manusia itu sendiri. Dalam suatu perusahaan sumber daya manusia merupakan bagian utama dalam pemrosesan masukan (input) menjadi keluaran (output) yang dihasilkan perusahaan (Suprihati, 2014). Kinerja yang baik akan terlihat jika individu dapat menyelesaikan dan melaksanakan tugasnya dengan baik ( Alannita, 2014). Kinerja merupakan hasil kerja seseorang selama periode tertentu dalam melaksanakan tugas dibandingkan dengan standar hasil kerja, target atau sasaran yang telah ditentukan dan telah disepakati (Hermawati, 2012). Lindawati (2012) menyatakan, kinerja individu adalah mengacu padaprestasi kerja individu yang diatur berdasarkan standar atau kriteria yang telah ditetapkan oleh suatu organisasi. Kinerja karyawan yang dinilai juga harus meliputi kinerja tugas (task performance) dan kinerja diluar tugas (non task performance atau contextual performance) (Motowidlo et al., 1997;

Motowidlo \& Van Scooter,1994).

Kinerja individu itu berasal dari 2 dimensi yaitu (task performance) dan(non task performance atau contextual performance)kedua jenis prilaku ini secara mandiri berkontribusi kepada kinerja keseluruhan (Koopmans, 2011).

Rumah sakit sebagai sarana kesehatan yang memberikan pelayanan kesehatan kepada masyarakat memiliki peran yang sangat strategis dalam mempercepat peningkatan derajat kesehatan masyarakatyang dapat diselenggarakan oleh pemerintah dan masyarakat. Menurut Kemenkes RI (2009), rumah sakit merupakan pusat pelayanan yang menyelenggarakan pelayanan medik dasar dan medik spesialistik, pelayanan penunjang medis, pelayanan perawatan, baik rawat jalan, rawat inap maupun pelayanan instalasi. Keberhasilan suatu rumah sakit tidak dapat diperoleh tanpa adanya kerja sama yang baik antar seluruh petugas kesehatan yang ada di rumah sakit tersebut. Salah satu petugas kesehatan yang memiliki peran penting di rumah sakit adalah 


\section{LIABILITIES (JURNALPENDIDIKAN AKUNTANSI) \\ e-ISSN 2620-5866 (Online) \\ http://jurnal.umsu.ac.id/index.php/LIAB \\ Vol. 4 No. 1 April 2021 Halaman $10-23$ \\ Doi: 10.30596/liabilities.v4i1.6844}

perawat. Perawat merupakan ujung tombak baik tidaknya pelayanan kesehatan yang diberikan kepada pasien, karena selama 24 jam perawat selalu berinteraksi dengan pasien. Keberhasilan dan pelayanan keperawatan sangat ditentukan oleh kinerja para perawat. Oleh karena itu, peningkatan kinerja perawat perlu dan harus selalu dilaksanakan melalui sistem yang terstandar sehingga hasilnya lebih optimal (Kuntjoro, 2015). Kinerja tugas dari seorang karyawan (perawat) dapat diukur melalui kemampuan menghasilkan pekerjaan yang berkualitas, terukur, tepat, dan sesuai dengan kebutuhan. Perawat dituntut juga harus mampu menyelesaikan masalah yang ada di lingkungan pekerjaannya, mampu berkomunikasi secara lisan dan tertulis, senantiasa memperbaharui pengetahuannya terkait dengan pekerjaannya. Sedangkan Kinerja kontekstual bagi perawat dapat diukur dari inisiatif yang dimiliki, antusias dan perhatian terhadap pekerjaan, memiliki dedikasi dan komitmen yang tinggi, memiliki hubungan interpersonal yang baik (Koopmans, 2011).
Namun sayangnya penelitian (Sinaga, 2018) dengan judul "Pengaruh Kepuasan Kerja terhadap Kinerja Perawat di Instalasi Rawat Inap Rumah Sakit Martha Friska Medan "menemukan bahwa masih ada perawat yang belum menyelesaikan tugasnya secara baik seperti melengkapi rekam medis pasien sesuai pemeriksaan yang telah dilakukan, sehingga perencanaan pengobatan dan perawatan yang akan diberikan kepada pasien menjadi terganggu. Kemudian masih adanya perawat yang tidak mengobservasi pasien secara rutin serta tidak mendokumentasikannya. Selanjutnya masih ada perawat yang belum mampumelakukan diagnosis dengan benar.

Kinerja karyawan dipengaruhi oleh beberapa faktor diantaranya adalah kepuasan kerja Kasmir (2016:65-71). Menurut Wijoyo (2014) Kepuasan kerja adalah suatu hasil perkiraan individu terhadap pekerjaan atau pengalaman positif dan menyenangkan dirinya. Berdasarkan hasil penelitian Sinaga (2018) menunjukkan bahwa terdapat pengaruh positif dan signifikan antara kepuasan kerja terhadap kinerja 


\section{LIABILITIES (JURNALPENDIDIKAN AKUNTANSI) \\ e-ISSN 2620-5866 (Online) \\ http://iurnal.umsu.ac.id/index.php/LIAB \\ Vol. 4 No. 1 April 2021 Halaman $10-23$ \\ Doi: 10.30596/liabilities.v4i1.6844}

perawat pada RS. Martha Friska

Medan. Dengan demikian apabila kepuasan kerja meningkat maka akan dapat meningkatkan kinerja perawat tersebut. Oleh karena itu kepuasan kerja ini penting untuk dikaji lebih lanjut guna meningkatkan kinerja yang lebih baik.

Salah faktor yang mempengaruhi kepuasan kerja adalah pemberian kompensasi kepada karyawan dapat memotivasidan memberikan kepuasan kerja. Menurut Mangkunegara (2015) kompensasi yang diberikan kepada karyawan sangat berpengaruh pada tingkat kepuasan kerja dan motivasi kerja, serta hasil kerja. Memberikan kompensasi yang sesuai dengan jenis pekerjaan dan jabatan kerja karyawan, maka karyawan akan merasakan kepuasand alam bekerja. Menurut penelitian (Manik, 2014), terdapat pengaruh kompensasi terhadap kepuasan kerja paramedis di Rumah Sakit Cibabat Kota Cimahi. Perawat dapat melaksanakan pekerjaannya jika ditunjang dari pemberian kompensasi baik kompensasi financial maupun nonfinancial, sehingga timbul motivasi dan kepuasan kerja perawat akan dapat meningkatkan kinerja perawat dalam melaksanakan asuhan keperawatan (Ngatemin \&Arumwanti, 2012). Menurut pendapat Gibson (2008:123-124) salah ada tiga faktor yang berpengaruh terhadap kinerja yaitu: (1) faktor individu meliputi kemampuan, keterampilan, latar belakang keluarga, pengalaman kerja, tingkat sosial, dan demografi seseorang, (2) faktor psikologis meliputi persepsi, peran, sikap, kepribadian, motivasi, dan kepuasan kerja, (3) faktor organisasi meliputi struktur organisasi, desain pekerjaan, kepemimpinan, sistem penghargaan (reward system). Berdasarkan uraian sebelumnya maka peneliti tertarik melakukan penelitian terkait denganpengaruh kompensasi terhadapkepuasan kerja dan dampaknya terhadap kinerja individu perawat pada beberaparumah sakit swasta di kota medan.

\section{KAJIAN LITERATUR}

\section{Kinerja}

Kinerja adalah kegiatan yang paling lazim dinilai dalam suatu organisasi, yakni bagaimana individu melakukan segala sesuatu yang berhubungan dengan suatu pekerjaan jawaban atau peran dalam organisasi. Kinerja adalah 


\section{LIABILITIES (JURNALPENDIDIKAN AKUNTANSI) \\ e-ISSN 2620-5866 (Online) \\ http://jurnal.umsu.ac.id/index.php/LIAB \\ Vol. 4 No. 1 April 2021 Halaman $10-23$ \\ Doi: 10.30596/liabilities.v4i1.6844}

hasil kerja yang dapat dicapai oleh seseorang atau sekelompok orang dalam suatu organisasi, sesuai dengan wewenang dan tanggung jawab masing-masing dalam rangkaupaya mencapai tujuan organisasi bersangkutan secara legal tidak melanggar hukum dan sesuai moral maupun etika (Nursalam, 2016).

Kinerja merupakan hasil pekerjaan yang mempunyai hubungan kuat dengan gaya strategis organisasi, kepuasan konsumen, dan memberikan kontribusi pada ekonomi (Wibowo, 2013). Kinerja adalah seperangkat hasil yang dicapai dalam merujuk pada tindakan pencapaian serta pelaksanaan suatu pekerjaan yang diminta (Sinambela, 2016).

Menurut Linda Koopmans kinerja individu di bagi atas 2 jeni yaitu : kinerja tugas (Task perfoemance) dan Kinerja Kontekstual (Contextual Performance), dimana masing-masing dari indikator kinerja tersebut dapat diuraikan sebagai berikut:

1. Indikator kinerja Tugas (Kualitas Pekerjaan, Kuantitas Pekerjaan, Bekerja dengan akurat dan tepat, Mampu menyelesaikan

permasalahan, Kemampuan
Komunikasi, dan Berkeinginan untuk selalu memperbaharuin pengetahuan)

2. Indikator kinerja Kontekstual (Insiatif, Antusiyasme dalam bekerja, pehatian tinggi terhadap pekerjaan, motivasi, didikasi, komitmen organisasi dan hubungan interpersonal.

Menurut Nursalam (2016) yang mengutip pendapat Gibson, ada tiga faktor yang mempengaruhi kinerja yaitu: faktor individu (kemampuan, keterampilan,latar belakang keluarga, pengalaman kerja, tingkat sosial, dan demografi seseorang), faktor psikologis (persepsi, peran, sikap, kepribadian, motivasi, dan kepuasan kerja), faktor organisasi (struktur organisasi, desain pekerjaan, kepemimpinan, dan sistem penghargaan).

\section{Kepuasan Kerja}

Menurut Robbins (2015: 170) disebutkan bahwa kepuasan kerja adalah suatu sikap umum terhadap pekerjaan seseorang sebagai perbedaan antara banyaknya ganjaran yang diterima pekerja dengan banyaknya ganjaran yang diyakini seharusnya diterima. 


\section{LIABILITIES (JURNALPENDIDIKAN AKUNTANSI) \\ e-ISSN 2620-5866 (Online) \\ http://iurnal.umsu.ac.id/index.php/LIAB \\ Vol. 4 No. 1 April 2021 Halaman $10-23$ \\ Doi: 10.30596/liabilities.v4i1.6844}

Menurut Kreitner dan Kinicki

(2014:169) sebuah tanggapan afektif atau emosional terhadap berbagai segi pekerjaan seseorang. Definisi ini secara tidak langsung menyatakan bahwa kepuasan kerja bukanlah sebuah konsep kesatuan. Namun seseorang bisa merasa cukup puas dengan salah satu aspek pekerjaannya dan merasa kurang puas dengan satu atau beberapa aspek lainnya.Dari berbagai pandangan tersebut kiranya dapat disimpulkan bahwa pada hakikatnya kepuasan kerja adalah kemampuan tingkat perasaan senang seseorang sebagai penulian postif terhadap pekerjaannya dan lingkungannya tempat kerjanya.

Menurut (Handoko, 2014) dalam Rivai indikator kepuasan kerja seorang karyawan dapat dilihat dari:

1. Isi pekerjaan Penampilan tugas yang diberikan serta sebagai kontrol terhadap pekerjaan tersebut.

2. Supervisi Pengawasan yang berkala dan selalu dilakukan oleh atasan agar pekerjaan yang diberikan terlaksana dengan baik.

3. Organisasi dan manajemen Kepuasan kerja akan tercipta jika adanya organisasi dan manajemen yang berjalan dengan baik.

4. Kesempatan untuk maju Dengan adanya kesempatan untuk maju maka karyawan termotivasi untuk melakukan pekerjaan sehingga timbulnya kepuasan kerja.

5. Gaji atau insentif Merupakan evaluasi karyawan terhadap pemenuhan kebutuhan hidup karyawan serta kesesuaian antara jumlah gaji dengan pekerjaan yang dilakukan.

6. Rekan kerja Adanya rekan kerja yang baik agar pekerjaan yang diberikan dapat terlaksana akan menciptakan kepuasan kerja.

7. Kondisi pekerjaan Kepuasan kerja bisa diperoleh seorang karyawan dengan dukungan kondisi lingkungan pekerjaan yang baik.

Kepuasan kerja dalam organisasi menghasilkan kinerja yang baik karena dapat meningkatkan produktivitas karyawan. Seseorang yang merasa puas dengan pekerjaannya akan merasa senang terhadap pekerjaan dan mendorong mereka untuk meningkatkan kinerja.

\section{Kompensasi}

Menurut Hasibuan

$(2017: 119)$ 


\section{LIABILITIES (JURNALPENDIDIKAN AKUNTANSI) \\ e-ISSN 2620-5866 (Online) \\ http://jurnal.umsu.ac.id/index.php/LIAB \\ Vol. 4 No. 1 April 2021 Halaman $10-23$ \\ Doi: 10.30596/liabilities.v4i1.6844}

Kompensasi adalah semua pendapatan yang berbentuk uang, barang langsung atau tidak langsung yang diterima karyawan sebagai immbalan atas jasa yang diberikan kepada perusahaan. Pembentukan sistem kompensasi yang efektif merupakan bagian penting dari manajemen sumber daya manusia karena membantu menarik dan mempertahankan pekerjaan-pekerjaan yang berbakat. Selain itu sistem kompensasi perusahaan memiliki dampak terhadap kinerja strategis.

Menurut Marwansyah (2016:269) Kompensasi adalah penghargaan atau imbalan langsung maupun tidak langsung, finansial maupun non finansial, yang adil dan layak kepada karyawan, sebagai balasan atau kontribusi/jasanya terhadap pencapaian tujuan perusahaan.

Dimensi dan indikator kompensasi sesuai dengan yang ada di peraturan dan dalam bentuk gaji, bonus, upah, hal tersebut dalam kompensasi finansial. namun dalam non finansialnya asuransi, tunjangantunjangan dan sebagainya. Setiap perusahaan memiliki indikator yang berbeda-beda dalam proses pemberian kompensasi untuk karyawan. Terdapat
2 (dua) dimensi yang dikemukakan oleh Veithzal Rivai (2011:357), yaitu :

1). Kompensasi finansial langsung, yang terdiri dari :

a. Gaji adalah balas jasa dalam bentuk uang yang diterima karyawan sebagai konsekuensi dari kedudukannya sebagai seorang karyawan yang memberikan sumbangan tenaga dan pikiran dalam mencapai tujuan perusahaan atau dapat juga dikatakan sebagai bayaran tetap yang diterima seseorang dari keanggotaannya dalam sebuah perusahaan.

b. Bonus adalah pembayaran sekaligus yang diberikan karena memenuhi sasaran kinerja atau uang yang dibayar sebagai balas jasa atas hasil pekerjaan yang telah dilaksanakan apabila melebihi target. Bonus juga merupakan kompensasi tambahan yang diberikan kepada seorang karyawan yag nilainya di atas gaji normalnya. Bonus juga bisa digunakan sebagai 


\section{LIABILITIES (JURNALPENDIDIKAN AKUNTANSI) \\ e-ISSN 2620-5866 (Online) \\ http://jurnal.umsu.ac.id/index.php/LAB \\ Vol. 4 No. 1 April 2021 Halaman 10 - 23 \\ Doi: 10.30596/liabilities.v4i1.6844}

penghargaan

terhadap

pencapaian

tujuan-tujuan

spesifik yang ditetapkan oleh

perusahaan, atau untuk

dedikasinya kepada

perusahaan.

c. Insentif merupakan imbalan langsung yang dibayarkan kepada karyawan karena kinerjanya melebihi standar yang ditentukan. Insentif merupakan bentuk lain dari upah langsung di luar upah dan gaji yang merupakan kompensasi tetap, yang biasa disebut kompensasi berdasarkan kinerja (pay for performance plan). Insentif adalah variabel penghargaan yang diberikan kepada individu dalam suatu kelompok, yang diketahui berdasarkan perbedaan dalam mencapai hasil kerja. Ini di rancang untuk memberikan motivasi karyawan berusaha meningkatkan produktivitas kerjanya.

2). Kompensasi tidak langsung (fringe benefit)

Kompensasi tidak langsung
(Fringe benefit) merupakan kompensasi tambahan yang diberikan berdasarkan kebijakan perusahaan terhadap semua karyawan sebagai upaya meningkatkan kesejahteraan para karyawan. Contohnya berupa fasilitas-fasilitas, seperti: asuransiasuransi, tunjangan-tunjangan, uang pensiun, dan lain-lain. (Sinaga, 2018) mengadakan penelitian mengenai "Pengaruh Kepuasan Kerja terhadap Kinerja Perawat di Instalasi Rawat Inap Rumah Sakit Martha Friska Medan"menyatakan bahwa Seluruh sub variabel kepuasan kerja berpengaruh secara signifikan terhadap kinerja perawat dalam melaksanakan asuhan keperawatan. (Manik, 2014) dalam penelitian yang berjudul "Pengaruh Kompetensi Dan Kompensasi Terhadap Kepuasan Kerja Serta Implikasinya Pada Kinerja Paramedis Di Rumah Sakit Cibabat Kota Cimahi" menyatakan bahwa Kompensasi kerja berpengaruh terhadap kepuasan kerja paramedis Rumah Sakit Cibabat Cimahi, namum pengaruhnya masih relatif 


\section{LIABILITIES (JURNALPENDIDIKAN AKUNTANSI) \\ e-ISSN 2620-5866 (Online) \\ http://jurnal.umsu.ac.id/index.php/LAB \\ Vol. 4 No. 1 April 2021 Halaman 10 - 23 \\ Doi: 10.30596/liabilities.v4i1.6844}

kecil yakni sebesar $26,6 \%$, besaran pengaruh tersebut menggambarkan bahwa pelaksanaan kompensasi pada Rumah Sakit Cibabat sudah memenuhi harapan untuk mempertahankan dan meningkatkan perlu adanya upaya implementasi secara optimal dan berkesinambungan (kontinu) terkait dengan peningkatan dan pengadaan kwalitas sarana dan prasarana kerja, standardisasi pelayanan, dan situasi kerja yang lebih aman, nyaman, dan kondusif. Sedangkan Kepuasan kerja berpengaruh terhadap kinerja paramedis Rumah Sakit Cibabat Cimahi, namum pengaruhnya masih relatif yaitu sebesar $2,9 \%$, ini menggambarkan bahwa tingkat capaian Kinerja paramedis pada Rumah Sakit Cibabat sudah baik untuk mempertahankan dan meningkatkan sehingga perlu adanya upaya implementasi secara optimal dan berkesinambungan terkait melengkapi sarana dan prasarana kerja disamping menciptakan suasana kerja yang aman, nyaman, dan kondusif. (Septianti, 2016) dalam penelitian yang berjudul "Pengaruh Kompensasi Terhadap Kepuasan Kerja Karyawan Pada Bagian Produksi Di PT. Etowa Packaging Indonesia" menyatakan bahwa Variabel kompensasi finansial berpengaruh secara signifikan terhadap kepuasan kerja karyawan di bagian produksi, hal ini dibuktikan juga dengan uji deskriptif yang didapatkan dari penilaian responden. Secara bersama-sama kompensasi finansial dan kompensasi non finansial berpengaruh terhadap kepuasan kerja karyawan di bagian produksi.

\section{METODE PENELITIAN}

Lokasi penelitian ini dilakukan pada beberapa rumah sakit swasta dikota Medan. Populasi penelitian ini adalah perawat yang bekerja di beberapa rumah sakit swasta di kota medan baik yang masuk kategori B ataupun $\mathrm{C}$. sedangkan teknik sampel menggunakan teknik simple random sampling. Model yang digunakan pada penelitian ini akan disajikan dalam bentuk persamaan moderasi dengan analisis regresi. Dalam pengumpulan 


\section{LIABILITIES (JURNALPENDIDIKAN AKUNTANSI) \\ e-ISSN 2620-5866 (Online) \\ http://jurnal.umsu.ac.id/index.php/LAB \\ Vol. 4 No. 1 April 2021 Halaman 10 - 23 \\ Doi: 10.30596/liabilities.v4i1.6844}

data peneliti menggunakan :

1. Kuisioner teknik pengumpulan data yang dilakukan dengan cara memberi seperangkat pernyataan tertulis kepada para perawat rumah sakit sebagai responden.

2. Wawancara teknik pengumpulan data dengan cara menggunakan pertanyaan lisan dengan pihak rumah sakit.

3. Studi dokumentasi teknik pengumpulan data dengan menggunakan literatur yang berhubungan dengan penlitian yang akan dilakukan.

\section{Analisis Data}

Data yang terkumpul di analisis menggunakan Persamaan Moderasi Dengan Analisis Regresi dengan bantuan SPSS 21.

\section{PEMBAHASAN DAN HASIL}

\section{Uji Partial(T)}

Uji $\mathrm{t}$ digunakan untuk mengetahui seberapa jauh pengaruh satu variabel independen secara individual dalam menerangkan variasi variabel dependen. Jika nilai $t$ hitung $>t$ tabel maka Ho ditolak, artinya variabel bebas berpengaruh positif terhadap variabel terikat. Jika nilai $\mathrm{t}$ hitung $<\mathrm{t}$ tabel maka Ho diterima, artinya variabel bebas berpengaruh negatif terhadap variabel terikat. Dimana $\mathrm{t}$ tabel dari peneiitian ini adalah 1,653 Hasil uji parsial dapat dilihat pada tabel berikut ini:

\section{Pengaruh Kompensasi Terhadap Kepuasan Kinerja}

\begin{tabular}{|c|c|c|c|c|c|c|c|}
\hline \multicolumn{8}{|c|}{ Coefficients $^{a}$} \\
\hline \multirow[t]{2}{*}{ Model } & \multicolumn{2}{|c|}{$\begin{array}{l}\text { Unstandardi } \\
\text { zed } \\
\text { Coefficients }\end{array}$} & $\begin{array}{l}\text { Standar } \\
\text { dized } \\
\text { Coeffici }\end{array}$ & $T$ & Sig. & \multicolumn{2}{|c|}{$\begin{array}{l}\text { Collinearity } \\
\text { Statistics }\end{array}$} \\
\hline & B & $\begin{array}{l}\text { Std. } \\
\text { Error }\end{array}$ & Beta & & & $\begin{array}{c}\text { Tolera } \\
\text { nce }\end{array}$ & $\begin{array}{l}\text { VI } \\
\text { F }\end{array}$ \\
\hline (Cons & 35. & 1.046 & & 33. & .00 & & \\
\hline tant) & 337 & & & 777 & 0 & & \\
\hline $1 \mathrm{KOM}$ & .39 & .041 & .570 & 9.5 & .00 & 1.000 & 1.0 \\
\hline PEN & 0 & & & 00 & 0 & & 00 \\
\hline SASI & & & & & & & \\
\hline
\end{tabular}

a. Dependent Variable: KEPUASAN KERJA

Dalam penelitian ini, derajat signifikan yang digunakan adalah 0,05 . Apabila nilai signifikannya < 0,05 maka hipotesis alternatifnya dapat diterima dimana ini menyatakan bahwa suatu variabel bebas secara parsial mempengaruhi variable terikat 


\section{LIABILITIES (JURNALPENDIDIKAN AKUNTANSI) \\ e-ISSN 2620-5866 (Online) \\ http://jurnal.umsu.ac.id/index.php/LIAB \\ Vol. 4 No. 1 April 2021 Halaman $10-23$ \\ Doi: 10.30596/liabilities.v4i1.6844}

serta derajat kebebasan (dk) dengan ketentuan n-3=187 diperoleh angka $t_{\text {tabel }}$ sebesar 1,653. Dengan ketentuan tersebut diperoleh variabel kompensasi memiliki $t_{\text {hitung }}>\mathrm{t}_{\text {tabel}}$, yaitu $9,500>1,653$ dan nilai signifikannya $0,00<0,05$ sehingga dapat disimpulkan bahwa kompensasi berpengaruh positif dan siginifikan terhadap kepuasan kerja perawat pada beberapa rumah sakit swasta di kota medan. Berdasarkan hasil tersebut, maka hipotesis pertama diterima.

\section{Pengaruh Kepuasan Kerja}

Terhadap Task Performance

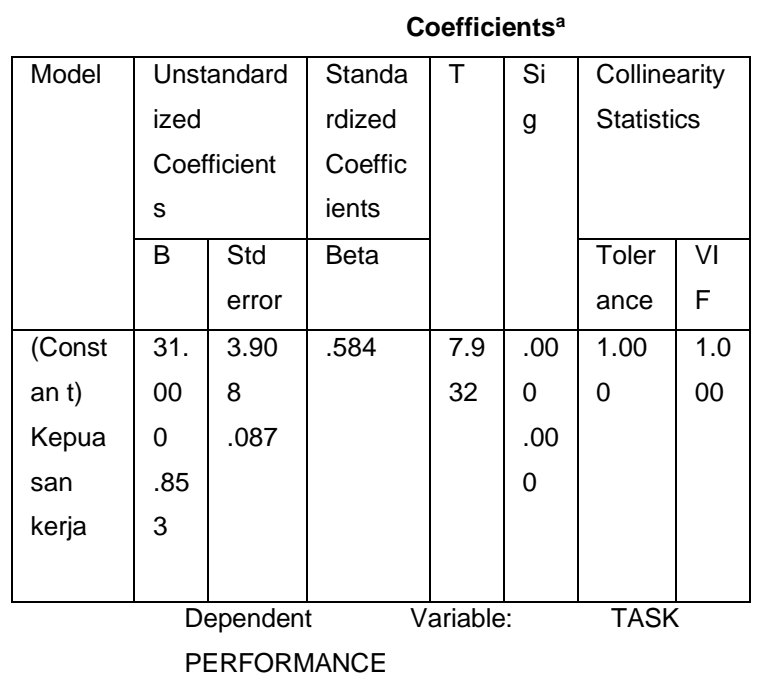

Dalam penelitian ini, derajat signifikan yang digunakan adalah 0,05 . Apabila nilai signifikannya < 0,05 maka hipotesis alternatifnya dapat diterima dimana ini menyatakan bahwa suatu variabel bebas secara parsial mempengaruhi variable terikat serta derajat kebebasan (dk) dengan ketentuan n-3=187 diperoleh angka $t_{\text {tabel }}$ sebesar 1,653. Dengan ketentuan tersebut diperoleh variabel kompensasi memiliki $t_{\text {hitung }}>t_{\text {tabel }}$, yaitu $9,859>1,653$ dan nilai signifikannya $0,00<0,05$ sehingga dapat disimpulkan bahwa kepuasan kerja berpengaruh positif dan siginifikan terhadap task performance perawat pada beberapa rumah sakit swasta di kota medan. Berdasarkan hasil tersebut, maka hipotesis kedua diterima.

\section{Pengaruh Kepuasan Kerja}

\section{Terhadap Contextual Performance}

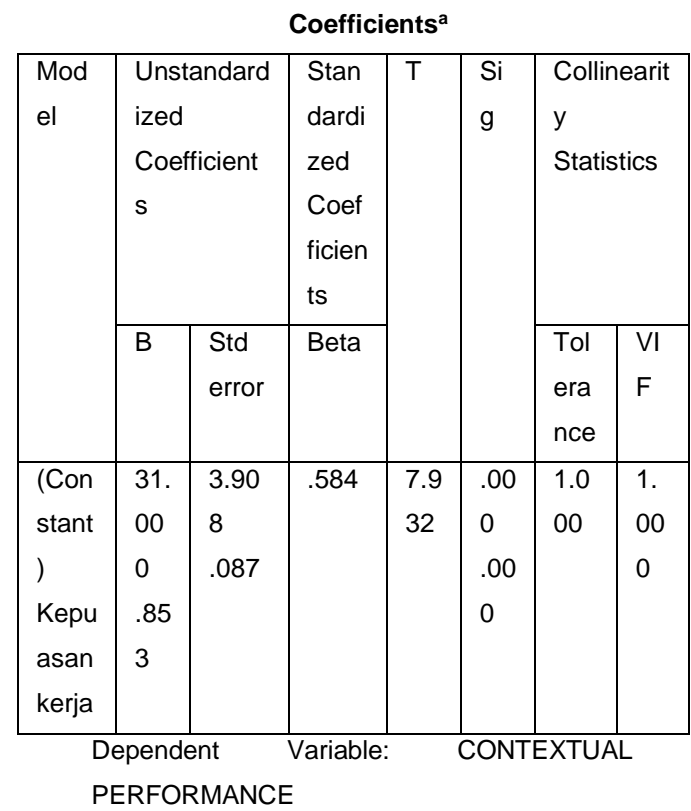

Dalam penelitian ini, derajat signifikan yang digunakan adalah 


\section{LIABILITIES (JURNALPENDIDIKAN AKUNTANSI) \\ e-ISSN 2620-5866 (Online) \\ http://jurnal.umsu.ac.id/index.php/LIAB \\ Vol. 4 No. 1 April 2021 Halaman $10-23$ \\ Doi: 10.30596/liabilities.v4i1.6844}

0,05 . Apabila nilai signifikannya <

0,05 maka hipotesis alternatifnya dapat diterima dimana ini menyatakan bahwa suatu variabel bebas secara parsial mempengaruhi variable terikat serta derajat kebebasan (dk) dengan ketentuan n-3=187 diperoleh angka $t_{\text {tabel }}$ sebesar 1,653. Dengan ketentuan tersebut diperoleh variabel kompensasi memiliki $t_{\text {hitung }}>\mathrm{t}_{\text {tabel }}$, yaitu $9,500>1,653$ dan nilai signifikannya $0,00<0,05$ sehingga dapat disimpulkan bahwa kepuasan kerja berpengaruh positif dan siginifikan terhadap contextual performance perawat pada beberapa rumah sakit swasta di kota medan. Berdasarkan hasil tersebut, maka hipotesis ketiga diterima.

\section{A. Pengaruh Kompensasi terhadap Kepuasan Kerja}

Berdasarkan analisis data pada penelitian ini dapat diketahui bahwa variabel Kompensasi mempunyai pengaruh positif dan signifikan terhadap Kepuasan Kerja perawat pada beberapa rumah sakit swasta di kota medan. Salah faktor yang mempengaruhi kepuasan kerja adalah pemberian kompensasi kepada karyawan dapat memotivasi dan memberikan kepuasan kerja. Menurut Mangkunegara (2015) kompensasi yang diberikan kepada karyawan sangat berpengaruh pada tingkat kepuasan kerja dan motivasi kerja, serta hasil kerja. Hal ini sesuai dengan penelitian sebelumya yang dilakukan oleh Manik (2014), terdapat pengaruh kompensasi terhadap kepuasan kerja paramedis di Rumah Sakit Cibabat Kota Cimahi.

\section{B. Pengaruh Kepuasan Kerja Terhadap Task Performance}

Berdasarkan analisis data pada penelitian ini dapat diketahui bahwa variabel Kepuasan Kerja mempunyai pengaruh positif dan signifikan terhadap Task Performance perawat pada beberapa rumah sakit swasta di kota medan. Kinerja karyawan dipengaruhi oleh beberapa faktor diantaranya adalah kepuasan kerja Kasmir (2016:65-71). Sinaga (2018) menunjukkan bahwa terdapat pengaruh positif dan signifikan antara kepuasan kerja terhadap kinerja perawat pada RS. Martha Friska Medan. 


\section{LIABILITIES (JURNALPENDIDIKAN AKUNTANSI) \\ e-ISSN 2620-5866 (Online) \\ http://jurnal.umsu.ac.id/index.php/LAB \\ Vol. 4 No. 1 April 2021 Halaman 10 - 23 \\ Doi: 10.30596/liabilities.v4i1.6844}

\section{Pengaruh Kepuasan Kerja Terhadap \\ Contextual}

\section{Performance}

Berdasarkan analisis data pada penelitian ini dapat diketahui bahwa variabel Kepuasan Kerja mempunyai pengaruh positif dan signifikan terhadap Contextual Performance perawat pada beberapa rumah sakit swasta di kota medan.

\section{KESIMPULAN DAN SARAN}

\section{Kesimpulan}

Berdasarkan hasil penelitian yang telah dilakukan maka peneliti menarik kesimpulan sebagai berikut :

1. Kompensasi mempunyai pengaruh positif dan signifikan terhadap Kepuasan Kerja perawat pada beberapa rumah sakit swasta di kota medan. Salah faktor yang mempengaruhi kepuasan kerja adalah pemberian kompensasi kepada karyawan dapat memotivasi dan memberikan kepuasan kerja

2. Kepuasan Kerja mempunyai pengaruh positif dan signifikan terhadap Task Performance perawat
3. Kepuasan Kerja mempunyai pengaruh positif dan signifikan terhadap Contextual Performance perawat

\section{Saran}

Saran pada penelitian ini adalah hendaknya pihak rumah sakit memberikan kompensasi yang setimpal kepada perawat agar menunjang kinerja perawat menjadi lebih baik lagi. Kinerja perawat yang baik akan menghasilkan pelayanan yang baik pula kepada pasien di rumah sakit.

\section{DAFTAR PUSTAKA}

A.A Anwar Prabu Mangkunegara. (2005). Manajemen Sumber Daya Manusia Perusahaan.

Bandung : Pt Remaja Rosdakarya

Departemen Kesehatan Ri. 2009. Undang-Undang Republik Indonesia Nomor 44 Tahun 2009 Tentang Rumah Sakit. Jakarta: Depkes Ri.

Handoko, B. (2014). Determinan Kepuasan Kerja Karyawan Pada Pt. X Medan. Manajemen \& Bisnis, 14(01), 7785.Motowidlo, S.J. ; Borman, W.C. ; Dan Schmit, M.J., 1997, A Theory Of Individual Differences In Task And ContextualPerformanc, Human Performance, 10 (2) : 71-83

Hermawati. (2012). Pengaruh Motivasi Dan Kemampuan 
Terhadap Prestasi Kerja

Pegawai Dinas Pendidikan

Pemerintah Kota Batu.Jurnal

Dinamika Dotcom, 3(2), 150-

156 Issn 2548-9917.

Koopmans, L. (2011). Conceptual

Frameworks Of Individual

Work Performance.Journal Of

Occupational And

Environmental Medicine,

53(8), 856-866.

Https://Doi.Org/10.1097/Jom.

0b013e318226a763

Motowidlo, S.J. Dan Van Scooter,

J.R., 1994, Evidence That Task

Performanxce Should Be

Distinguished From

Contextual Performance,

Journal Of Applied

Psychology, 79 (4) : 475-480

Mangkunegara,A.A. 2015.

Evaluasi Kinerja Sumber

Daya Manusia.

Bandung:Refika Aditama.

Manik, E. (2014). Pengaruh

Kompetensi Dan Kompensasi

Terhadap Kepuasan Kerja

Serta Implikasinya Pada

Kinerja Paramedis Di Rumah

Sakit Cibabat Kota

Cimahi.Ekonomi, Bisnis \&

Entrepreneurship, 8(2), 62-72

Issn 2443-0633.

Ngatemin\&ArumwantiW.(2012).Pe

ngaruh Kompetensi Dan

Kompensasi Terhadap

Motivasi Kerja Karyawan Di

Kabupaten Karo Provinsi

Sumatera Utara. Jurnal Riset

Akuntansi Dan Bisnis, Vol. 12

No. 2 